\title{
Mapping Competencies of Educational Lecturers in Industrial Revolution Era 4.0
}

\author{
$1^{\text {st }}$ Junaidi H. Matsum* \\ Tanjungpura University, Pontianak, Indonesia \\ prof.junaidimatsum@gmail.com
}

\begin{abstract}
This review articles employed the method of comprehensive summary and perspective onthestate of the field, in this case, education allecture competencies. The results of this discussion depict that higher education should beaimedat having graduated with the competence to apply science and technology that are ableto competeat regional, national and international levels by prioritizing devotion, independence, and intelligence. One of the things that can bed one to deal with ther evolution era 4.0 isto improve the competencies of lecturersand students. Lecturer competencies include strong core competencies, softskills, critical thinking,
\end{abstract}

\section{INTRODUCTION}

Initially, information communication and technology (ICT) was only used to search for information, but over time, ICT was widely used by various fields of science, especially in the world of education. Technology tends to change from time to time. In the era of industrial revolution 4.0 (hereinafter abbreviated as IR4), technology has become an important thing in the professional world. The job market requires a combination of various different skills from those that have been provided by the education system. In the era of IR4 digital technology has very broad application, can be used beyond the classrooms, campus boundaries, and even the country, it must begin to be built with a structured and comprehensive roadmap. According to [1] the core of Education 4.0 focuses on the learning management that helps the students to develop their skills by implementing the new technology in which it creative, communicative, and able to collaborate well with students; in addition, educational competenceis also a demand, including competence in research, competence for digital business, competence in globalization, and competence in future strategies. Lecturers can adjust their abilities with the development of science and technology. The digital tool can make it easier to communicate and carry out instructional activities. The courses should integrate the use and position of digital technology in the learning system.

Keywords-Competency, Lecturer, Industrial Revolution 4.0

follows the society changes. It means lecturers and students are able to make use of the development of information and technology to support the teaching and learning process in this era.

The new literacy movement is intended to focus on three main literacies namely, 1) digital literacy, 2) technology literacy and 3) human literacy (Aoun, 2017 in [2]). One of the policies that can be taken by the university is the development of a cyber university that is prepared for online learning. Thus, in implementing the learning process, the competence of lecturers needs to be developed to keep abreast of the times. Lecturers are the spearhead of knowledge in higher education. By taking this fact into account, this paper aims to discuss the competencies of the educational lecturer in the era of industrial revolution 4.0 in order to break down the barriers of technological development. 


\section{The era of the Industrial Revolution}

During the Industrial Revolution 1, the industry was introduced to mechanical production facilities using hydropower and steam (1874). Work equipment which initially depended on human and animal power was eventually replaced by the machine. In the era of the industrial revolution 2, there began to be an introduction to mass production, based on the division of labor. Then, in the era of the industrial revolution 3 already used electro nics and information technology, to automate production. This computer-based automation system makes industrial machines no longer human-controlled. As a result, production costs become cheaper. Furthermore, in the era of industrial revolution 4.0 was marked by cyber-physical. Furthermore, IR4 is charac terized by the presence of digital programs and the use of massive artificial intelligence in many sectors of human life, especially in the economic field [3].

According to [4] IR4 has several elements which are: (1) Social Machines. Sophisticated machines interact like humans with online social media. (2) Global Facility and Virtual Production. Company machines are connected to the provider and customer systems [5]. (3) Smart Products. Each product produced data storage (operations, status, material, the origin of the provider, consumer, etc.), and (4) Smart Servies. Products that have been marketed and are in the hands of consumers can still collect and send data related to the behavior of using the product. So producers can develop their products [5].

The industry is starting to touch the virtual world, in the form of human, machine \& data connectivity. Known as the Internet of Thing (IoT). There is a merging of digital \& internet technology with conventional technology. This is in line with the opinion of [6] which states that IR4 is a comprehensive transformation of all aspects through the merger of digital \& internet technology with conventional technology. The aim is to increase produc tivity, efficiency, and customer satisfaction.

There is a relationship between the IR4 era, particularly for education in Indonesia. The
IR4 era implicitly requires education to conform. Lecturers and students in the future are challenged to adapt and be able to improve and develop their competencies in using digital technology-based learning methods appropriately, including using Android in the teaching-learning process. For this reason, IR4 can be a trigger for students to think critically, competitively, creatively, and innovatively. According to [7] in the current industrial era, lecturers provide teaching materials via e-mail or Slideshare, then in the process of learning, they use LCD that is connected to their laptop and sometimes uses e-learning. Students use their laptop to deepen lecture materials. In the [8], it mentions the appropriate types of skills needed in the IR4 era including (1) complex problem solving, (2) coordinating with others, (3) social management, (4) critical thinking, (5) negotiation, (6) quality control, (7) service orientation, (8) judgment and decision making, (9) active learning, and creativity.

Recently, the era of disruption is predicted, in which it is an era in where there will be many new skills that must be possessed by students so that the old ones will become obsolete, even considered old-fashioned. Thus, teachers must be able to keep up with the development of technology. Therefore, professional teachers must be aware of and adapt themselves to this development. Teachers of this digital age should develop their learning mindset, possess digital literacy, keen on learning new things, and should able to make use of chances that IR 4.0 offers in order to achieve better learning results for their students. It is also a demand for the teacher to integrate classroom activities with some online platforms in order to spark students' attention and interest. All in all, if the teachers now are adequately competent, thus all developments in the IR 4.0 will considerably give positive impacts on the achievement of our national education goals for a better future.

\section{Lecturer Competencies}

In the learning process in higher education, lecturers are the most decisive component in the overall education system, which must receive the main attention. Lecturers can 
determine the success of their students in relation to the learning process and learning. In this sense, [9] stated that educators have a pivotal role in education, they are bounded up with responsibility for the quality of education. Recognition of the quality of higher education is determined, among other things, by the quality of the lecturer. Improving the quality of lecturers, among others, can be done by increasing the competence of lecturers. [10\} argued that competence is a major component of professional standards in addition to a code of ethics as a regulation of professional behavior set in certain procedures and supervision systems.

Generally, lecturer professionalism covers the competencies described in Law No. 14 of 2015 [11] concerning teachers and lecturers. Some competencies that must be possessed by educators are pedagogic, personality, social, and professional competencies. [10] posited that educators who are said to be professional should have minimum requirements that include having adequate educational qualifications, scientific competencies relevant to their fields, being able to communicate with their students, creative and productive spirit, work ethic and high commitment to the profession, and always developing themselves through professional organizations, books, seminars, etc.

Pedagogical competence at least includes (1) understanding of insight or educational foundation; (2) understanding of students; (3) curriculum/syllabus development; (4) learning design; (5) the implementation of instructional and dialogical learning; (6) utilization of learning technology; (7) evaluation of process and learning outcomes; and (8) student development to actualize the various potentials it has. Minimal personality competencies include personalities that are: (1) steady; (2) stable; (3) adult; (4) wise and wise; (5) authoritative; (6) noble character; (7) set an example for students and society; (8) objectively evaluating one's own performance; and (9) developing themselves independently and sustainably. Social competence is intended to have the ability to: (1) communicate oral, written, and / or signaling; (2) using communication and information technology functionally; (3) associating effectively with students, fellow lecturers, education staff, parents/guardians of students; and (4) socializing politely with the surrounding community. Social competencies such as: (1) being inclusive, acting objectively, and not discriminatory because of consideration gender, religion, race, physical condition, family background, and socioeconomic status; (2) communicating effectively, empathically, and politely with fellow educators, educational staff, parents, and the community; (3) adapt to places of assignment throughout the territory of the Republic of Indonesia which have socio-cultural diversity; and (4) communicating with one's own professional community and other professions verbally and in writing or in other forms. Then, the professional competencies that must be possessed by lecturers, for example: (1) mastering the material, structure, concepts, and supporting scientific thought patterns subjects studied; (2) developing course material that is taught creatively, broadly, and deeply; (3) develop professionalism on an ongoing basis by taking reflexive actions; and (4) utilizing information and communication technology to develop themselves.

\section{METHOD}

This scientific work employed the study of various theories that discuss the competencies of the educational lecturer in the era of industrial revolution 4.0 in order to meet the challenges of technological development. Existing theories are studied in-depth, associated with various opinions of experts covering two sub-points of discussion. First, facing the era of the industrial revolution 4.0 and second, the competence of education lecturers in the era of the industrial revolution 4.0.

\section{RESULTS AND DISCUSSION}

\section{Facing the Industrial Revolution Era 4.0}

Advances in science and technology which experienced extraordinary speed and acceleration, put pressure on human behavior to be able to meet the needs and demands of life. In the field of education, this raises new 
awareness to revitalize the performance of the teaching profession in order to prepare students as future generations of young people who are able to respond to the progress of science and technology, needs, and demands of society. The declaration of teachers and lecturers as a profession by President Soesilo Bambang Yudhoyono became one of the accelerators born of Law No. 14 of 2005. In this IR4 era, the recognition of teachers and lecturers as professionals and professionals is increasingly apparent. Recognition of the position of teachers and lecturers as professionals serves to raise the dignity and role of learning agents on campus to improve the quality of national education in Indonesia. Science and technology both as the substance of teaching materials and tools for organizing learning continue to develop. This dynamic requires lecturers to always improve and adjust their competencies to be able to develop and present course material that is appropriate and actual, using a variety of approaches, methods, learning models, and the latest learning technology.

The learning process organized by lecturers is conducive to achieve goals actively, creatively, effectively, and excitingly because it is supported by the use of modern and reliable learning technology. In this way, the lecturer is able to organize learning that successfully leads students into the world of life in accordance with the needs and challenges of the IR4 era. As a result, the education and learning system products are ready to plunge into the changing real-world. On the contrary, the unwillingness and inability of the lecturer to adjust his insight and competence to the demands of the development of his professional environment will actually be one of the factors inhibiting the achievement of educational and learning goals. Thus, the challenges of the IR4 era need to be responded to by lecturers massively.

[12] stated that in 2030 about $50 \%$ of employment is threatened by being dominated by a computerized system. This happened as the world entered into the era of the industrial revolution 4.0 when odor intelligence took a vital role in the development of digital technology. The change will occur on a large scale, including new forms of employment. The current government and private institutions require new skills from their employees as technology develops. According to Parray (as cited in [13])Indonesia needs to improve the quality of the skills of workers with digital technology. Based on the opinion above, lecturers and students should continue to adjust to fast-moving technology, always improve skills, among others, in the ability of learning and innovation. Lecturers are expected to have strong Core Competencies supported by developing soft skills of themselves including critical thinking and complex problem solving, creative thinking, innovation, communication, and collaboration.

\section{Lecturer Competencies in Industrial Revolution Era 4.0}

Generally speaking, with the advent of globalization and modernization, it is a must to improve the quality of education. Improving quality of education would enable the individuals to satisfactorily achieve academic goals and enhance the standing of educational institutions within the community. Furthermore, the educators will incur the feeling of job satisfaction, develop motivation towards the implementation of their job duties and feel pleasurable within the working environment [14].

It can be said, that lecturers are the most influential component towards the creation of quality educational processes and outcomes. Therefore, any improvement efforts undertaken to improve the quality of education will not make a significant contribution without the support of professional and qualified lecturers. One of the improvements in the quality of lecturers is through developing their competencies in learning.

Competency can be interpreted by ability or ability, and or authority. Lecturer competence is an ability or skill that is reflected in the behavior of lecturers in realizing their learning performance. [15] explains that the issue of teachers' competence is something that is very essential. These 
competencies are information communication and technology competencies, which are developed using the technology literacy approach, knowledge deepening, and knowledge creation. Thus, the statement highlights the issue of lecturer competence. In essence, lecturers are central to efforts to improve the quality of education. Therefore, every effort to improve tertiary education will and must involve structuring and reforming the teaching profession.

The industrial revolution era 4.0 demands new literacy movement which intended to focus on three main competencies of literacies namely, 1) digital literacy, 2) technology literacy and 3) human literacy (Aoun, 2017 in [2]). These three skills are predicted to be competencies that are essentially needed in the IR 4.0 era. Digital literacy is aimed at developing the ability to read, analyze, and use information in the digital world (Big Data), technology literacy aims to provide a comprehension of the workings of machinery and technology applications, and human literacy directed at improving communication skills as well as mastery of design science (Aoun [2]). The new literacy provided is expected to create competitive graduates by perfecting the old literacy movement which only focuses on improving the ability to read, write and mathematics. Adaptation of new literacy movements can be integrated and adjusted to the curriculum and learning system. These ideas confirm the $21^{\text {st }}$-century learning principles and approaches presented by [16].

In addition, the competence of lecturers in the IR4 era was successfully programmed to be improved by certain principles. The competency improvement program developed by the principles includes: (1) scientific, comprehensive material and activities which become content and competencies that must be scientifically justified; (2) relevant, taskoriented and function as professional educators who have pedagogical, personal, social, and professional competencies; (3) systematic, each component of the competency (4) actual and contextual, namely competencies and indicators that can be used in the development of science and technology; (5) flexible, formulation of competencies and indicators can be adjusted according to the needs and developments of the times; (6) Updating, each lecturer fostered and developed his profession to obtain quality competencies and performance to provide education in competencies that produce knowledge, competencies, are able to become their own, and can support life with others; (7) independent, every lecturer who is continuously empowered to be able to improve the competencies that are enhanced, thereby increasing professional independence in carrying out the duties and functions of the profession; (8) professional, coaching and professional development carried out by promoting the values of professionalism; (9) effective, the implementation of coaching and professional development must provide information that can be used as a basis for making appropriate decisions by parties related to the profession in improving their competency competencies; and (10) efficient (funds, personal, time), the implementation of coaching and professional development based on consideration of the use of resources to a minimum to obtain optimal results.

\section{CONCLUSIONS}

To sum up, in the era of industrial revolution 4.0, increasing the quality of the skills of lecturers and students with digital technology has become a necessity. In this sense, lecturer competency in the industrial revolution era 4.0 requires core competencies, educational competence, competence in research, competence for digital business, competence in globalization, competence in future strategies and training soft skills such as critical thinking and complex problem solving, creative thinking, innovative communication and collaboration.Generally speaking, higher education graduates can be competitive if there is a curriculum upgrade oriented towards KKNI and the Industrial Revolution. 4.0. In addition,lecturers should discover methods to develop cognitive capacity: higher-order mental skills, critical thinking, systemic, and entrepreneurship through thematic studies of various 
disciplines, relationships with the real world, project-based learning, curricular and extracurricular, and internship or practical work.Human literacy becomes part of general education that students must acquire and master. Moreover, if data literacy and technology are applied in elective courses; therefore, students will be ready to become intelligent humans who are computer literate (Coding). All in all, ICT offers the best opportunity to increase productivity (effectiveness and efficiency) in maintaining the quality of education.

\section{ACKNOWLEDGMENTS}

I would like to show my gratitude to Rahayu Meliasari, M.Pd, IKIP PGRI Pontianak for translating this scientific work thoroughly.

\section{REFERENCES}

[1] Puncreobutr, V. (2018). Education 4.0: New challenge of learning. St. Theresa Journal of Humanities and Social Science, 2(2), pp. 92-97. Retrieved from http://www.stic.ac.th/ojs/

[2] Yahya, M. Era. (2018). Industri 4.0: Tantangan Dan Peluang Perkembangan Pendidikan Kejuruan Indonesia. Pidato Pengukuhan Penerimaan Jabatan Professor Tetap dalam Bidang Ilmu PendidikanKejuruan Fakultas Teknik Universitas Negeri Makassar.

[3] Schwab, Klaus. (2016). The Fourth Industrial Revolution: what it means. How to Respon. Retrieved from https://www.wforum.org/agenda/2016/0 1/the-fourth-industrial-revolution-whatit-means-and-how-to-respon/

[4] Federasi Industri Jerman. (2016). What is Industry 4.0? Retrieved from http://english.bdi.eu/article. new/whatis-Industry-4.0/
[5] Lee, J., dkk. (2013). Recent Advances and Trends in Predictive Manufacturing Systems in Big DataEnvironment. Manufacturing Letters 1, pp. 38-41.

[6] Merkel, A.Speech by Pederal Chansellor Angela Merkel. (2014). OECD Conference. Retrieved from https://www.bundesregierung.de.Conte ntRogent.2014/2014-02/19-oecd-merkelparis en.html

[7] Rudito, Priyanto dan Sinaga, Mardi F.N. (2017). Digital Mastery Membangun Kepemimpinan Digital untuk Memenangkan Era Disrupsi. Jakarta: PT Gramedia Pustaka Utama.

[8] World Economic Forum (WEF). (2015). New Vision for Education: Un Locking the Potential of Technology. Geneva: WEF.

[9] Yamin, M. dan Maisah. Standarisasi Kinerja Guru. (2010). Jakarta: Gaung Persada (GP Press).

[10] Mulyasa. (2011). Manajemen Berbasis Sekolah, Konsep, strategi dan Implementasi. Bandung : PT Remaja Rosdakarya.

[11] Republic of Indonesia Law No. 14 Year 2015 on Teacher and Lecturer.

[12] Hendri, Irfani. (2018). Membangun Kesiapan Hadapi Revolusi Industri 4.0. Pontianak: Koran Pontianak Post.

[13] Ahmad, Intan. (2018). Proses Pembelajaran Digital Dalam Era Industri 4.0. Jakarta: Direktur Jendral Pembelajaran dan Kemahasiswaan, Kemenristekdikti.

[14] Kapur, Radhika. (2019). Improving Quality and Efficiency of Education. Research Gate.

[15] UNESCO ICT Competency Fream Work for Teachers. (2011). Paris: UNESCO.

[16] Trilling, B \& Fadel, C. (2011). 21 $1_{\text {st-century }}$ skills: learning for life in our times. US: Jossey-Bass A Wiley Imprint. 